\title{
From deficiency to development: the evolution of academic skills provision at one UK university
}

\section{Pat Hill}

University of Huddersfield, UK

\section{Amanda Tinker}

University of Huddersfield, UK

\section{Stephen Catterall}

University of Huddersfield, UK

\begin{abstract}
This article discusses the context in which study support has emerged in higher education in the UK. Within this context the article documents the establishment of a 'devolved model' of academic skills at the University of Huddersfield. Whilst acknowledging that this model is not unique, its formation allows for the exploration of pedagogical and practical issues. It highlights the complexity of providing support which is effective and viable, recognising that the increasing diversity of the student body calls for multiple strategies. An examination of the evolution of the provision at Huddersfield illustrates the journey from a focus on student deficit and retention towards one clearly associated with learning development. This model assumes an integrated, flexible and student centred approach within the subject discipline, rather than one which is extra-curricular and may be perceived as remedial. Originally predicated on the individual student tutorial and standalone workshop, the provision is now focusing on working within the disciplines to embed academic development within the curriculum.
\end{abstract}

Keywords: academic skills provision; learning development; embedding. 


\section{Introduction}

The massive increase in UK undergraduate numbers, often referred to as widening participation, has meant a departure from an elitist provision catering for a small minority of the population. This minority, privileged by intellect or social status, was seen as including'those with ideas, with intellectual creativity and with capacities for cultural innovativeness' (Thompson, 2000:161). Higher education now seeks to develop a wider range of individual potential for the benefit of society as a whole (Radford et al., 1997:17). There is an argument that even this change has been overtaken by 'a rhetoric of business models and market relations' (Walker, 2006: 6) and has become too closely linked with the notion of employability. Many of those involved in study support, however, will not see these different purposes of higher education as mutually exclusive, as the question will always be approached from the individual student perspective. If any of these purposes are to be achieved without lowering standards, then a range of support is required to ensure that every learner develops in a way which allows them fully to contribute to and benefit from higher education.

This article explores the place of learning development in higher education with particular reference to two issues. The first is the legacy of remedial provision and a move towards development rather than deficiency; the second is how a devolved provision may provide opportunities for an embedded approach which situates academic development within the discipline. Beginning with an overview of the contentious issues related to the place of learning development within a higher education framework, there follows a description and evaluation of the model adopted at Huddersfield, a post-1992 University with over 24,000 students. The article details the journey from a retention-focused initiative towards an inclusive, responsive and embedded provision aimed at enhancement and achievement for all.

\section{The changing face of 'study support' in higher education}

Higher education institutions have recognised the need to consider ways in which a greater number of students can be helped to meet the criteria necessary to succeed. This has 
generated a great deal of research and scholarship. Although the majority of the research outlined here is concerned with writing, many of the issues raised are pertinent to all disciplines and skills. Lea and Street's much cited work on academic literacies has resulted in a heightened awareness of the need to be more explicit in what is required of students. Their insistence on 'a more encompassing understanding of the nature of student writing within institutional practices, power relations and identities' (Lea and Street, 1998: 158) has rightly prompted a more student centred focus which acknowledges different student experiences and rejects a 'student deficit' approach. Another major shift has been the move away from separate study skills provision to a more embedded approach which sites writing practices at the heart of academic work rather than at the periphery (Creme and Lea, 1999).

A major influence in moving towards the embedding of study support within the curriculum has been insights from the American experience which has seen a shift from separate provision towards Writing across the Curriculum (WAC) and Writing in the Disciplines (WiD) approaches. In a keynote speech to the Writing Development in Higher Education Conference, David Russell of lowa University maintains that the trick is to raise awareness without segregating writing development' (Russell, 1999). In her article 'Doing away with Study Skills', Wingate draws heavily on this American experience, and on learning theory, to suggest that separate or 'bolt-on' study skills provision 'has severe limitations' (Wingate, 2006: 457). Whilst acknowledging these limitations, however, it is important to maintain as wide a range of provision as possible so that students can choose the most appropriate support for their individual learning development. As Blythman et al. (2003:196) point out, 'the key issue is not whether students are suitable for tutoring, but rather how the institution can respond to meet the learning needs of all students'. Ganobcsik-Williams' call for a 'comprehensive, whole institution provision' (2004:34) is clearly paramount, yet there are many practical and logistical issues which institutions face, even if the pedagogical and epistemological will is in place. This article documents how the University of Huddersfield has responded to these challenges as it seeks to meet student needs in a developmental and sustainable way.

As noted by Wingate (2006: 457), any provision already in place before the large expansion of higher education was firmly based on a remedial approach, as it was assumed that most 
students coming into higher education would already have the necessary academic skills. Remedial provision was generally offered outside the discipline in the form of optional courses provided by support centres and students were identified as failing. Wall (2006: xii) indicates the effect of this remedial approach upon student perceptions:

Non-embedded skills teaching, such as non-curricular writing classes, tends to be perceived negatively by many students. To attend them at all is seen to be a public admission of failure...to attend the writing class on grammar or punctuation, referencing or structuring an essay, is to admit that you can't do it. You are at university, perhaps even studying English Literature, and you cannot perform the basic routines of competence in your subject.

There is a growing body of evidence to support an inclusive approach to academic development. Research has shown that both traditional and non-traditional students find themselves ill-prepared for the demands of self-directed academic study at this level, with a third of 7,109 survey respondents finding 'academic work harder than they had expected it to be' (Yorke and Longden, 2008: 7). A Quality Assurance Agency (QAA) for Higher Education review of transition suggests that the discussion should move beyond perceptions of student deficit to one of 'enhancement', an approach 'which values and builds on existing strengths, skills and knowledge regardless of learner profile' (Whittaker, 2008: 26). Institutions have to find ways of developing students' learning and writing practices without attracting the traditional stigma associated with such input.

In identifying the main areas of contention in the successful provision of study support, Blythman et al. (2003: 203) identified 'five key areas': (1) Geographical and structural location; (2) Staffing; (3) Co-operation and liaison; (4) Resourcing; and (5) Strategic factors. All five areas are considered within a broad framework here but have been adapted to illustrate particular circumstances and concepts relevant to the Huddersfield case. For instance, in examining the impact of location on provision, the choice of name was also viewed as an important factor in how the provision is perceived. 


\section{Challenging different priorities and perceptions}

The Association for Learning Development in Higher Education (ALDinHE) has recently debated the topics of location and naming. A survey of member institutions conducted by the Learning Development in Higher Education Network (LDHEN, now ALDinHE) showed that the majority of over forty respondents had centrally based study support (Association for Learning Development in Higher Education, 2008). In on-line discussion (LDHEN jiscmail discussion, 2007a), the location of support was seen as extremely significant in how that support is perceived. The discussion confirmed that the majority of correspondents were still centrally based in libraries, study skills centres, learning development or support units. Some respondents stressed the importance of establishing links with the different departments and the need to become more accessible and visible, citing breakfast clubs and a presence in cafés as one way to reach reluctant students. Those based within departments appeared to value the inclusiveness and collaboration that this engendered. Overall, location was seen as part of a marketing issue where accessibility, visibility and status are clearly linked with student demand.

The name of the service was viewed as another marketing tool in making learning development attractive to students (LDHEN jiscmail discussion, 2007b). Divergence from a remedial ethos is reflected in the popular choice of the word 'development' which has in some instances been specifically chosen to replace 'support', both in relation to models of provision and job titles such as 'learner developers'. Acronyms with positive associations are also popular, for example CLASS, WISER, ASK, SPLASH and UpGRADE. The discussion showed that new services were giving a great deal of thought to the choice of a name which would have no corrective or remedial associations. This is an ongoing consideration; as detailed below, Huddersfield has Academic Skills Tutors (ASTs) but there has recently been discussion within the team about whether the word 'skills' has the right connotations (see Lillis, 2001: 22 for a discussion of 'writing-as-skill').

Another key issue covered by the survey was staffing. Data was collected about the level of expertise of those involved and this has implications for the status and role of the service in terms of student perceptions, other staff members and the institution generally. According to the survey, the staff involved in academic development range from part-time hourly paid or 
fixed contract staff classed as 'admin' through to permanent principal lecturers. Some institutions recorded only one part-time member of staff whilst at the other end of the scale was a Learning Development Unit with 30 full time members of staff and 30 hourly paid lecturers. As Turner (2000: 49) suggests, the changes in higher education 'as a result of socio-economic forces and the demands of the quality assessment perspective' are leading to a measurable increase in learning support. The roles asked of these staff might span first year student workshops to extensive staff training and development. The wide variety of provision reflects the post-' 92 university focus on support but increasingly pre-'92 universities are acknowledging the need for learning development that can be given through a variety of channels. The recent appointment of a Learning Development Adviser at Oxford University is a good example of this (Oriel College, University of Oxford, 2008). Finance is another important issue which has implications for the provision of an effective service and the LDHEN survey also revealed the variety of funding sources. The sources named included the Higher Education Funding Council for England (HEFCE), the Higher Education Academy, Teaching Quality Enhancement Funds (TQEF) and Widening Participation Funds as well as 'centrally funded', 'top sliced' and 'core' funding. Some institutions showed a mixture of funding which was reviewed within a fixed time period. These resource issues illustrate the complex challenges that face institutions wishing to establish learning support.

\section{Establishing a devolved provision}

Within the context of these challenges, in 2002 the University of Huddersfield implemented a devolved model of academic skills development within subject disciplines. The successful HEFCE and TQEF project bid has resulted in at least one permanent Academic Skills Tutor (AST) in each of its seven Schools and two University Centres. The key aim of this three year project was to establish 'a distributed academic skills unit' (Academic Skills Tutors, University of Huddersfield, 2005, title page) for the University. This would provide students with support for the non-subject aspects of their work, with a target of 200 student contacts by the year 2004; a target which has since been dramatically exceeded. Despite academic skills provision being commonplace in many universities in a centralised form, the AST appointments were still the subject of controversy in the national press, perpetuating perceptions of a deficiency model: 
Huddersfield University is advertising for 'academic support tutors' to help students 'with grammar' and 'to read academic books'. How have we arrived at a state where universities are recruiting remedial teachers to help students with basic reading and writing skills? Letter from Magill (cited by Woodhead, 2002)

Although the project sought to move away from this climate of student deficit, it has to be acknowledged that addressing retention was an underlying issue. In addition to establishing a devolved Academic Skills Service, part of the project was to develop a diagnostic tool (named the Individual Learning Profile) for all first year undergraduates to enable early identification of students potentially 'at risk' of non-progression; this process is still in use in some schools but not all.

Initially, the role of the Academic Skills Tutor was focused on individual students via one-toone tutorials and driven by the students' academic needs, usually focused around their assignments. Figure 1 below shows the number of requests under various categories in which individual students sought advice:

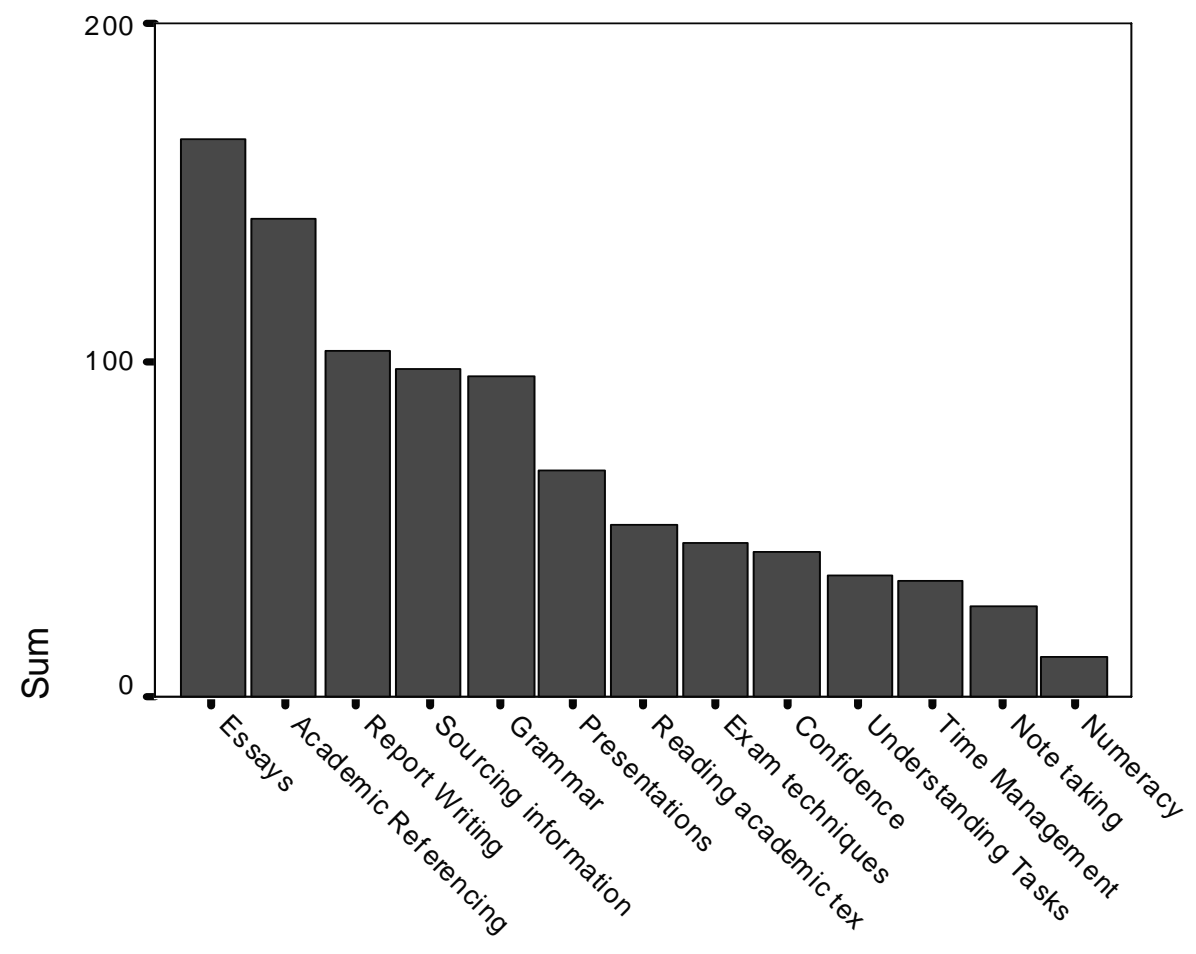

Figure 1. Areas in which students sought support from their AST during the academic year 2003/04 (Academic Skills Team, University of Huddersfield, 2005: 11). 
The demand for tutorials has successively increased year on year (see Figure 2) leading to additional tutor appointments in some Schools. The university now has thirteen permanent (eleven full-time equivalent) ASTs across three different centres (Huddersfield, Oldham and Barnsley). All are appointed on academic contracts and have both teaching and postgraduate qualifications, including four with doctorates.

Figure 2 illustrates that the rather tentative target of 200 contacts in 2002/03 was grossly underestimated. Demand continues to increase, although it should be acknowledged that the number of students seen is still relatively small in proportion to the whole student body.

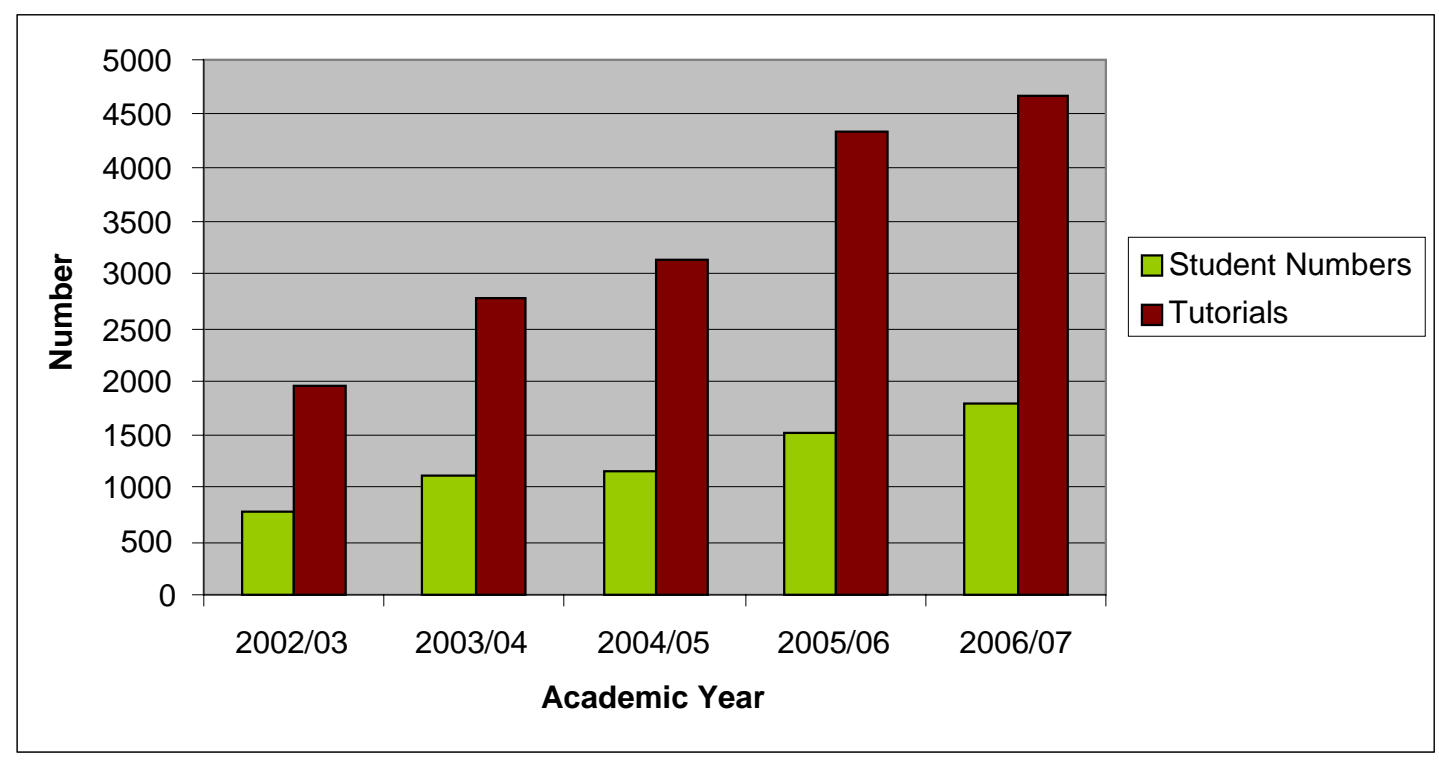

Figure 2. Growth in tutorials and student numbers, 2002-2007.

Such one-to-one provision has proved successful in meeting its initial aim of retention. Evaluation of the devolved model indicated a correlation between academic skills development and retention; students who had seriously considered leaving their course and then stayed, often attributed this decision to AST support. This figure rose from $57 \%$ in 2004 , to $74 \%$ for 2005 (Academic Skills Team, University of Huddersfield, 2005). Qualitative comments from students also reflected this:

I had seriously considered leaving my course and my Academic Skills Tutor was my first point of contact. Without her support and encouragement I would not be here now. Before meeting with my Academic Skills Tutor I was going to leave the course. 
I feel that if this support had not been available I would have left after the first few months.

This service helps to keep students like me at University.

If this service wasn't available I don't know what l'd have done to complete.

The Academic Skills Tutor has been a lifeline to myself and many others over the past three years, many of whom would have left in the first year, myself included. (Academic Skills Tutors, University of Huddersfield, 2005)

This contribution to retention and transition was also supported by the QAA in the University's institutional audit:

The University's internal evaluation of the AST system concluded that the service was highly valued and a major contributor to retaining students at the University; the audit team had no reason to dissent from this finding...it has the capacity to improve the confidence of some first-year students who might otherwise not thrive. Overall, it seemed to the team that the University's development of its AST scheme represented a feature of good practice. (Quality Assurance Agency for Higher Education, 2004: 24)

However, in addition to retention the impact on achievement was also noticeable, with $79 \%$ of students saying that the Academic Skills Tutors had made a 'significant contribution' to improvement in their coursework (Academic Skills Team, University of Huddersfield, 2005). Again, this quantitative result was supported by comments from students:

The academic skills tutor personalised advice to my specific needs and was able to explain things on a level I was able to understand...I have attained firsts in two modules this year thanks to your help. 
My grades have started to improve and I will be going for advice in my second year. This gives me the confidence to carry on in my university life.

[The AST] has helped me achieve grades A and B through the first year as it is scary moving from $A$ level to university level education.

He has been very helpful, as I was upset about my first essay. He helped me understand where I had gone wrong. My second essay came back with a high grade due to the help I had received. (Academic Skills Tutors, University of Huddersfield, 2005)

However successful this has been, the percentage of students seen makes it apparent that this strategy needs to be made more inclusive; increasing tutor numbers to meet individual tutorial demand is not sustainable in terms of cost efficiency and meeting diverse student need. Moreover, individual tuition will not suit every style of learning; some students may respond to this informal, personal approach specifically tailored to their own needs whilst other students may seek more independent learning. For instance, evaluation in the School of Music, Humanities and Media in 2004/5 showed a pronounced gender imbalance where female students seeking advice outnumbered male students by five to one. This was addressed by using more in-class activities and focusing promotion on developmental success rather than support; figures for 2007/8 show a marked improvement. Multiple strategies are therefore essential in ensuring that learning development becomes an integral part of all student experience.

\section{Diversity, inclusion and multiple strategies}

The provision at Huddersfield has expanded beyond individual tutorials and stand alone workshops in response to this need. To cater for students who prefer a more formal environment where they can engage in practical exercises, group work and discussion, ASTs developed a range of strategies, including longer induction sessions, English for Academic Purposes (EAP) courses, workshops tailored and integrated into modules (involving close liaison with course tutors) and module or co-module leadership, including assessment. One 
useful addition has been a social book-marking site (http://www.del.icio.us.com) which allows all students access to a range of material; this is selected by ASTs from various websites and grouped under appropriate headings with evaluative comments and, where possible, tailored to the subject discipline. Originally used as a stand-alone resource, this is now being more frequently integrated into student tutorials and taught sessions.

Group sessions foster a developmental ethos, being timely, relevant, linked to the subject curriculum and devolved into each School. In attending such sessions, students also become aware of the AST's physical location and developmental role within the School. This challenges any traditional perceptions of deficit and encourages students to take advantage of the provision to realise their potential. This is also reflected in how students first make contact with their AST. Although course tutors may refer a student who they feel would benefit from additional academic support, a large proportion of students now self-refer, often as a result of AST group sessions, a recommendation to a course cohort by tutors, or student word of mouth (ASTs often see a particular student, followed by a succession of their peers). Although this move from working solely with individuals to incorporate group sessions has been successful, it was recognised that there was still potential to integrate the provision more fully and this has led to further initiatives.

\section{Embedding and curriculum development}

The question has progressed to how the nature of the devolved provision can be adapted and further improved rather than whether it should exist at all. Current dialogue involves discussion of how academic skills can be further embedded within the curriculum (Hill and Mullen, 2007; Byrne and Tinker, 2007). This is working towards the 'build-up' model advocated by Dowling and Ryan (2007: 18) which 'emphasises the importance of developing learners' academic skills on a progressive, staged basis throughout their programme of study'. The provision has now changed from being purely focused on students to include engagement with subject discipline staff. These relationships with staff have been developed over a number of years and, as Blythman and Orr (2006) observe, they can be complex and difficult. There are several schemes involving a WiD approach which aim to integrate writing development into subject learning either through staff development or module design (see Ganobscik-Williams, 2004: 29-35 for an overview and details of initiatives which have been 
funded). The closer disciplinary links established by having ASTs within Schools would appear to be an advantage; even within a devolved model, however, there are challenges in working with the different perceptions of academic skills provision. Staff development on related issues has become a growing element in the work of ASTs. Conversations are becoming more frequent between ASTs and subject staff at the curriculum development stage, although this is still dependent on recognising timely opportunities and encouraging change with receptive staff.

There are currently various initiatives across the University which reflect this collaboration. ASTs in the Business School are co-operating with subject staff to take this concept beyond 'one-off' skills sessions to embed both academic skills and personal development planning into specific modules as part of curriculum development for accountancy undergraduates (English and Ireland, 2008). In the School of Art, Design and Architecture, a previously stand alone, first year, study skills module has been successfully embedded into subject discipline modules at the most relevant points in year one with plans to take this forward into subsequent years two and three. Although embedded, the 'long-thin' module is assessed by way of a progressive reflective portfolio in which students articulate and evidence their learning development. They are thus encouraged to view their course programme and learning holistically, recognising links beyond a modular structure (Squires et al., 2009). This has proved to be a transformative learning experience for many students:

Understand what you have actually learnt... helped me see that I have been learning and not noticed [it].

Changed how I will record my learning in the future ... additionally my formal writing technique has improved.

I now understand how I have developed ... and shows my achievements...thoughtful and gives direction. 
I've found that reflecting on your work allows you to see how and what you can improve and where your strengths lie. I also find it a form of self encouragement and it shows how you are gradually growing. (Academic Skills Tutors, University of Huddersfield, 2005)

A further example of progress is the request for the ASTs in the School of Music, Media and Humanities to contribute to a Learning and Teaching Committee Working Group to discuss specific ways in which learning development can be embedded in first year curricula; two first year modules have been identified as pilots where the ASTs can work with the module leaders as the curriculum is adapted. These ad hoc initiatives are currently being discussed amongst ASTs with a view to how School-based conversations can be converted into university-wide strategies. Huddersfield is not alone in seeking to establish consistency and parity of student experience across the University.

One example is the University of Brighton, who had a longstanding ethos of embedded support based around a mixture of carefully designed first year curricula, with staged assignments to help diagnose problems and develop academic skills, personal tutoring and, in some courses, discrete study skills modules, supplemented by some central provision (Ridley, 2009). Although this approach had 'gained the University consistently high ratings in external reviews', Brighton decided to survey its provision in response to perceived concerns about increasing demands on staff time and the need to maintain 'curriculum content and rigour' (Ridley, 2009). This review revealed a great deal of effective study support but marked variations in the student experience across the university, with little cross-referencing between central and local support. One of the key recommendations (since implemented) was for improved coordination and sharing of information and materials across the University.

In a bid to foster the desired coordination, ASTs at Huddersfield, although devolved into the Schools, work closely as a team and meet on a regular basis to discuss areas of common interest and issues relevant to their work with students. However, recent meetings have highlighted the ambition to translate localised embedding initiatives within schools to a more formal, university-wide provision. The aim is to create sustainable and more systematic 
embedding of skills at the curriculum development stage without losing discipline-specific focus. As Gibbs (2009: 9) suggests:

Efforts will have to change from working with individual students to working with teachers, courses, degree programmes and the whole institution, in ways that are aligned with other institutional efforts, as part of a broad strategy, and that these efforts will need to be well conceptualised and backed up with convincing empirical evidence of impact.

Huddersfield appears well-placed to be at the forefront of these changes, and it is recognised that an expanded collection of relevant data could be a way of realising this 'empirical evidence', which would contribute to university-wide strategies.

\section{Conclusion}

The 'widening participation' agenda promoted the view of study support as necessary remedial intervention for non-traditional students who lacked the skills to succeed in higher education. Within this climate, the University of Huddersfield's initial response was to focus on students deemed 'at risk', with an underlying motivation to address retention. However, in contrast with the more usual central provision, a devolved model where tutors worked within Schools was established, giving the advantages of closer links with subject staff and students, and an awareness of specific curriculum and assessment demands. The provision expanded organically through a three-phase journey. An initial concentration on student-centred, individual tutorials was extended to incorporate multiple strategies and work with larger groups. This second phase moved towards a more inclusive and sustainable approach to address diverse student need and to promote achievement and academic development for all. The third phase has recognised the need for integration, and more progressive rather than one-off sessions. Although one-to-one sessions are still a major component, as Gibbs (2009) predicts, there is now also a focus on staff development, curriculum design and embedding at point of need within the subject discipline. In line with Ganobcsik-Williams' call for 'a whole institution approach' (2004), our challenge now is to employ best practice from across the University with a focus on teaching processes, staff development and recording documentary 
evidence. Small scale initiatives can then be expanded to achieve more coordination, thus fully realising parity of student experience.

\section{References}

Academic Skills Team, University of Huddersfield (2005) TQEF project: the establishment of a distributed academic skills unit for the university. Unpublished report. University of Huddersfield.

Association for Learning Development in Higher Education (2008) Working documents: LDHEN, January 2008. ONLINE: http://www.aldinhe.ac.uk/docs.htm (Accessed: 14 April 2008).

Blythman, M., Mullin, J., Milton, J. and Orr, S. (2003) 'Implementation issues for study support', pp. 195-208, in Bjork, L., Brauer, G., Rienecker, L. and Stray Jorgenson, P. (eds.) Teaching academic writing in European higher education. USA: Kluwer Academic Publishers.

Blythman, M. and Orr, S. (2006) 'Mrs Mop does magic', Zeitschrift Schreiben 9 pp 1-8. ONLINE: http://www.zeitschrift-schreiben.eu/Beitraege/blythman orr MrsMop.pdf (Accessed: 12 August 2009).

Byrne, G. and Tinker, A.J. (2007) 'Localised 'one-stop' shops: a devolved, embedded model of academic skills provision', Crossing boundaries: academic support for the learner in HE, Middlesex University, Hendon, Middlesex, 30 June.

Crème, P. and Lea, M.R. (1999) 'Student writing: challenging the myths', pp. 1-13, in Thompson, P. (ed.) Academic writing in higher education: perspectives, explorations and approaches. Proceedings of the $5^{\text {th }}$ Annual Writing Development in Higher Education Conference. University of Reading 1-2 April 1998. Reading: Centre for Applied Language Studies, University of Reading. 
Hill, Tinker and Catterall From deficiency to development: the evolution of academic skills provision at one UK university

Dowling, L. and Ryan, O. (2007) 'Academic skills development and the enhancement of the learning experience', All Ireland Society of Higher Education Conference: Teaching and Learning in Changing World of Higher Education. National University of Ireland, Maynooth 30-31 August. ONLINE: http://www.aishe.org/events/20062007/conf2007/proceedings/paper-32.pdf (Accessed: 12 August 2009).

English, J. and Ireland, C. (2008) 'Developing the tools of the trade: reconciling vocational and academic demands', 'Doing University': Student Transitions and Skills in Higher Education. University of Huddersfield, Huddersfield 19 March.

Ganobcsik-Williams, L. (2004) A Report on the teaching of academic writing in UK higher education. ONLINE:

http://www.rlf.org.uk/FELLOWSHIPSCHEME/documents/TeachingWritingUKHE.pdf (Accessed: 10 August 2009).

Gibbs, G. (2009) 'Developing students as learners - varied phenomena, varied contexts and a developmental trajectory for the whole endeavour', Journal of Learning Development in Higher Education 1: 1-12. ONLINE:

http://www.aldinhe.ac.uk/ojs/index.php?journal=ildhe\&page=article\&op=view\&path\%5B \%5D=30\&path\%5B\%5D=14 (Accessed: 17 August 2009).

Hill, P. and Mullen, J. (2007) 'The study skills conundrum: writing skills - an integrated approach', 4th Association for Learning Development in Higher Education Conference (ALDinHE). Bournemouth University, Bournemouth 12 April.

LDHEN jiscmail discussion (2007a) 'Location of study skills/learning support', LDHEN Jiscmail discussion list, 16-21 February [online]. Available e-mail: Idhen@jiscmail.ac.uk (Accessed: 21 February 2007).

LDHEN jiscmail discussion (2007b) 'Service names', LDHEN Jiscmail discussion list, 3־4 May [online]. Available e-mail: Idhen@jiscmail.ac.uk (Accessed: 4 May 2007). 
Hill, Tinker and Catterall From deficiency to development: the evolution of academic skills provision at one UK university

Lea, M. R. and. Street, B. V. (1998) 'Student writing in higher education: an academic literacies approach', Studies in Higher Education 23 (2) pp 157-172.

Lillis, T (2001) Student writing: access, regulation, desire. London: Routledge

Oriel College, University of Oxford (2008) LearnSmart: getting the most out of Oxford. ONLINE: http://www.oriel.ox.ac.uk/content/294 (Accessed: 14 April 2009).

Quality Assurance Agency for Higher Education (2004) University of Huddersfield, institutional audit, December 2004. ONLINE:

http://www.qaa.ac.uk/reviews/reports/institutional/Huddersfield04/Huddersfield04.pdf (Accessed: 10 August 2009).

Radford, J., Raaheim, K., de Vries, P. and Williams, R. (1997) 'Quantity and quality in higher education', Higher Education Policy, series 40. London: Jessica Kingsley.

Ridley, P. (2009) E-mail to Pat Hill, 7 August.

Russell, D. (1999). 'Learning to write and writing to learn across the university: the US experience', pp. 1-13, in Graal, M. and Clark, R. (eds.) Proceedings of the $6^{\text {th }}$ Writing Development in Higher Education Conference: Partnerships Across the Curriculum. 20-21 April. Leicester: Teaching and Learning Unit, University of Leicester.

Squires, P., Tinker, A. J. and Redmore, N. (2009) 'Reflect, connect and plan: an integrated Learning Portfolio', Enhancing the First-Year Experience: Theory, Research and Practice. $4^{\text {th }}$ Annual European First Year Experience Conference. University of Groningen, University Medical Center, Groningen, The Netherlands 13-15 May. ONLINE: http://www.efye.eu/presentations.html (Accessed: 18 August 2009).

Thompson, G .F. (2000) 'Towards a relegitimation of higher education: reinvigorating the humanities and social sciences', pp. 150-164, in Brown, R.H. and Schubert, J.D. (eds.) Knowledge and power in higher education: a reader. New York: Teachers College Press. 
Turner, J. (2000) 'Academic literacy and the discourse of transparency', pp. 149-160, in Jones, C. (ed.) Students' writing in the university: cultural and epistemological issues. USA: John Benjamins Publishing Company.

Walker, M. (2006) Higher education pedagogies: a capabilities approach. Maidenhead: Open University Press.

Wall, A. (2006) 'Introduction', pp. xi-xv, in Davies, S., Swinburne, D. and Williams, G. (eds.) Writing matters: the Royal Literary Fund report on student writing in higher education. London: Royal Literary Fund.

Whittaker, R. (2008) Quality enhancement themes: the first year experience - transition to and during the first year. Mansfield: The Quality Assurance Agency for Higher Education. ONLINE:

http://www.enhancementthemes.ac.uk/documents/firstyear/Transition\%20\%20Final.pdf (Accessed: 10 August 2009).

Wingate, U. (2006) 'Doing away with 'study skills', Teaching in Higher Education 11(4) pp 457-469.

Woodhead, C. (2002) 'Chris Woodhead: answer the question', The Times, 20 September. ONLINE:

http://www.timesonline.co.uk/tol/news/article815346.ece?token=null\&offset=12\&page= 2 (Accessed: 12 August 2009).

Yorke, M. and Longden, B. (2008) The first year experience of higher education in the UK: final report. York: Higher Education Academy. ONLINE: http://www.heacademy.ac.uk/assets/York/documents/ourwork/research/surveys/FYE/F YEFinalReport.pdf (Accessed: 10 August 2009). 


\section{Author details}

Dr Pat Hill is an experienced lecturer in English language. She has been an Academic Skills Tutor in the School of Music, Humanities and Media at the University of Huddersfield for five years and is presently co-leading a cross-university Teaching and Learning Project on embedding Learning Development within the curriculum.

Dr Amanda Tinker has been Academic Skills Tutor in the School of Art, Design and Architecture since 2002. Having the additional role of Learning Development Team Leader, she has strategic responsibility for the School's Virtual Learning Environment and other learning resources. She is a chartered librarian, with a PhD in information retrieval.

Dr Stephen Catterall has been the Academic Skills Tutor in the School of Computing and Engineering since 2002 and has a background in research and teaching in the humanities and social sciences and more latterly in learning development. He has been involved in a university sponsored project to develop diagnostic assessment of student IT, literacy and numeric skills in the School and is also a Disability Coordinator. 